CZASOPISMO INŻYNIERII LĄDOWEJ, ŚRODOWISKA I ARCHITEKTURY JOURNAL OF CIVIL ENGINEERING, ENVIRONMENT AND ARCHITECTURE

JCEEA, t. XXXIV, z. 64 (3/I/17), lipiec-wrzesień 2017, s. 547-558, DOI: 10.7862/rb.2017.145

\author{
Stanisław WIERZBICKI ${ }^{1}$ \\ Zbigniew PIÓRO \\ Marcin OSINIAK ${ }^{3}$ \\ Edward ANTOSZKIEWICZ ${ }^{4}$
}

\title{
ZASTOSOWANIE INKLINOMETRÓW W MONITORINGU KONSTRUKCJI
}

\begin{abstract}
W pracy omówiono zagadnienie pomiaru lokalnych zmian kątów obrotu elementów konstrukcji, jako metody monitorowania zachowania się ustroju konstrukcyjnego. Celem prowadzonych badań i analiz jest opracowanie metody pomiarów, która mogłaby zostać wykorzystana w systemach monitoringu konstrukcji, jako alternatywa dla tradycyjnego pomiaru przemieszczeń realizowanego dalmierzami laserowymi. Zaproponowano wykorzystanie inklinometrów z czujnikami MEMS, charakteryzującymi się dobrymi właściwościami metrologicznymi przy akceptowalnych kosztach. Przeanalizowano zalety i ograniczenia tej metody w relacji do alternatywnego pomiaru przemieszczeń dalmierzami laserowymi. Omówiono możliwości zastosowania inklinometrów do monitorowania typowych ustrojów konstrukcyjnych, a także przedstawiono przykład systemu monitoringu technicznego wykorzystującego taką metodę pomiaru.
\end{abstract}

Słowa kluczowe: monitoring konstrukcji, pomiary przemieszczeń, pomiary kątów obrotu, inklinometr MEMS, system bezprzewodowy

\section{Wprowadzenie}

Jednym z najbardziej istotnych zagadnień związanych z każdym obiektem budowlanym jest zapewnienie bezpieczeństwa konstrukcji. Wymaga to odpowiedniego przebiegu procesu projektowania i realizacji inwestycji, jak też późniejszej eksploatacji obiektu. Z danych uzyskanych w ramach projektu MONIT „Monitorowanie Stanu Technicznego Konstrukcji i Ocena jej Żywotności”, rea-

\footnotetext{
${ }^{1}$ Autor do korespondencji / corresponding author: Stanisław Wierzbicki, Politechnika Warszawska, Instytut Inżynierii Budowlanej, al. Armii Ludowej 16, 00-637 Warszawa; tel. +48 2223465 60; s-wierzbicki@il.pw.edu.pl

2 Zbigniew Pióro, WiSeNe Sp. z o.o., ul. E. Dembowskiego 6, 02-784 Warszawa, tel. +48 2222702 08; zbigniew.pioro@wisene.pl

${ }^{3}$ Marcin Osiniak, WiSeNe Sp. z o.o., ul. E. Dembowskiego 6, 02-784 Warszawa, tel. +48 2222702 08; marcin.osiniak@wisene.pl

${ }^{4}$ Edward Antoszkiewicz, WiSeNe Sp. z o.o., ul. E. Dembowskiego 6, 02-784 Warszawa, tel. +4822 22702 08; edward.antoszkiewicz@ wisene.pl
} 
lizowanego przez Politechnikę Warszawską wraz z kilkoma innymi jednostkami naukowo-badawczymi, wynika, że przyczyny awarii i katastrof budynków rozkładają się prawie równomiernie na wszystkie trzy ww. etapy, a więc projektowania, realizacji i eksploatacji obiektu - rys. 1. [1, 2, 3]. Z przeprowadzonych analiz wynika też, że większość katastrof miała miejsce w budynkach o konstrukcji stalowej lub mieszanej stalowo-żelbetowej (rys. 2.), a więc takich, które charakteryzują się znacznym udziałem obciążeń zmiennych w całości oddziaływań. Przy losowości występowania oddziaływań klimatycznych, nawet wadliwie zaprojektowana lub wykonana tego typu konstrukcja może przez wiele lat bezawaryjnie pracować i dopiero wystąpienie ekstremalnych wartości tych obciążeń może doprowadzić do awarii lub katastrofy.

W tym kontekście zasadne jest rozwijanie i stosowanie metod oraz środków mających za zadanie zwiększenie bezpieczeństwa użytkowania konstrukcji. Jedną z takich metod jest monitoring konstrukcji, szczególnie przydatny właśnie w przypadku wspomnianych wyżej lekkich ustrojów nośnych.

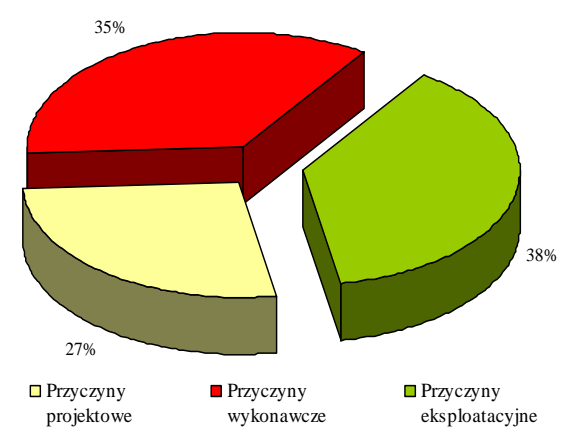

Rys. 1. Podział przyczyn awarii i katastrof

Fig. 1. Factors responsible for building incidents

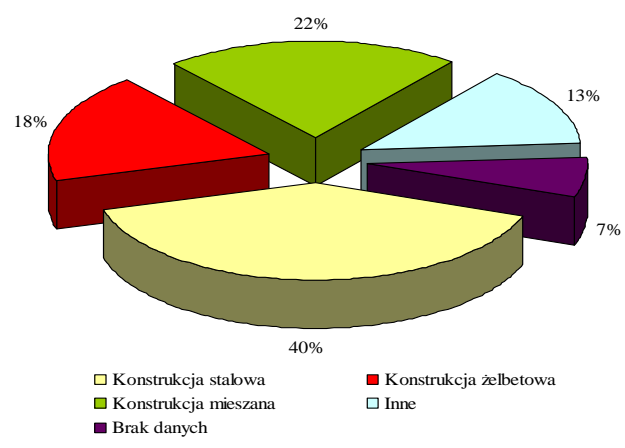

Rys. 2. Podział awarii i katastrof ze względu na typ konstrukcji

Fig. 2. Incidents by construction type

Znaczenie zagadnień monitoringu konstrukcji znalazło swoje odzwierciedlenie $w$,Warunkach technicznych, jakim powinny odpowiadać budynki...” (Dz.U. z 2009 r. Nr 56 poz. 461, §204, ust. 7) [4], w których wprowadzono wymóg stałego monitorowania parametrów istotnych dla bezpieczeństwa konstrukcji (przemieszczenia, odkształcenia, naprężenia) w obiektach użyteczności publicznej, takich jak: hale widowiskowe, sportowe, dworcowe, wystawowe, obiekty handlowe.

Podstawowym celem stosowania monitoringu konstrukcji jest oczywiście poprawa bezpieczeństwa jej użytkowania. Zapewniający osiągnięcie tego celu system może być jednocześnie pomocny w procesie utrzymania obiektu, ułatwiając kontrolę ciężaru zalegającej na dachu pokrywy śnieżnej i ostrzegając 
o gromadzeniu się na dachu nadmiaru wody w trakcie intensywnych opadów deszczu, np. przy ograniczonej drożności instalacji odwadniającej.

Typowy system monitoringu konstrukcji jest zestawem współpracujących ze sobą urządzeń i sterującego nimi oprogramowania, które w sposób stały realizują pomiary odzwierciedlających pracę konstrukcji wielkości, archiwizują i analizują wyniki tych pomiarów oraz generują, na tej podstawie, odpowiednie sygnały i informacje. Bardzo istotną częścią systemu monitoringu są więc zainstalowane w obiekcie różnego rodzaju urządzenia pomiarowe. W zależności od możliwości systemu oraz od rodzaju konstrukcji, wynikających stąd wymagań i ograniczeń, monitorowane są najczęściej wielkości takie jak: przemieszczenia, odkształcenia, temperatura i charakterystyki dynamiczne, a w niektórych przypadkach także zjawiska pogodowe oraz stosowane są metody wizyjne.

\section{Metody pomiaru przemieszczeń}

Prostym i często stosowanym rozwiązaniem w monitoringu konstrukcji jest pomiar przemieszczeń, które pozwalają uzyskać informacje o zachowaniu się elementu/ustroju konstrukcyjnego albo fragmentu konstrukcji. W praktyce istnieje wiele różnych metod pomiaru przemieszczeń, z których w systemach monitoringu konstrukcji najczęściej wykorzystywane są pomiary wykonywane przy pomocy dalmierzy laserowych, rzadziej tachimetrów i niwelatorów hydrostatycznych, które są stosowane raczej do obiektów mniej typowych, wymagających indywidualnego podejścia (jak np. stadiony). Podobnie wygląda sytuacja z GPS, przy czym w tym przypadku dochodzi jeszcze problem z uzyskaniem odpowiedniej dokładności, co w wielu przypadkach dyskwalifikuje takie rozwiązanie. Różnego typu metody pomiarowe zostały omówione m.in. w [5, 6] oraz w raportach z przytoczonego wyżej projektu MONIT.

Urządzeniem charakteryzującym się dobrymi parametrami pomiarowymi jest tachimetr elektroniczny, który w pełni automatycznie może wykonywać pomiary przemieszczeń wielu punktów konstrukcji z dokładnością nawet do $1 \mathrm{~mm}$. W metodzie tej wymagana jest jednak dobra widoczność (brak przeszkód i odpowiednia przezierność powietrza) na drodze pomiędzy tachimetrem a monitorowanymi punktami. Istotną wadą tachimetrów jest cena, która praktycznie eliminuje je z prostszych (i zarazem tańszych) systemów monitoringu, a w przypadkach, w których są one wykorzystywane, często stosuje się pojedyncze urządzenia, co oznacza ryzyko unieruchomienia całego systemu w sytuacji usterki tachimetru oraz w czasie okresowych przerw konserwacyjnych. Problem można częściowo zniwelować, stosując pomocniczą metodę pomiaru, która w takich przypadkach umożliwi funkcjonowanie systemu monitoringu w minimalnym, podyktowanym względami bezpieczeństwa, zakresie.

Do tego celu może być wykorzystana np. technologia GPS, wolna od niekorzystnych cech, jakie są związane z tachimetrami, cechująca się jednak innymi ograniczeniami. Pierwszym z nich jest stosunkowo niska dokładność - przy po- 
miarach przemieszczeń pionowych można przyjąć, że jest to około (+/-) $5 \mathrm{~mm}$, co w wielu przypadkach jest niewystarczające. Druga, niekorzystna cecha, to konieczność uzyskiwania bieżących, płatnych poprawek ze stacji referencyjnych, zapewniających odpowiednią dokładność pomiarów.

Innym rozwiązaniem jest, działający na zasadzie naczyń połączonych, niwelator hydrostatyczny, umożliwiający wykonywanie pomiarów przemieszczeń pionowych w zakresie do $100 \mathrm{~mm}$, z dokładnością nawet do 0,01 mm. Pewnym ograniczeniem $\mathrm{w}$ zastosowaniu takiego rozwiązania jest sieć rurek $\mathrm{z}$ cieczą podatnych na uszkodzenia w trakcie bieżącej eksploatacji i konserwacji konstrukcji. Mimo prostoty samej metody i możliwej do uzyskania dużej dokładności pomiarów, nie znalazła ona zbyt szerokiego zastosowania w systemach monitoringu.

W systemach bazujących na przemieszczeniach, najczęściej stosowane są dalmierze laserowe - proste i stosunkowo niedrogie urządzenia o dokładności rzędu $1 \mathrm{~mm}$, a więc wystarczającej do celów monitoringu technicznego. Pomiar dalmierzem laserowym cechuje się jednak pewnymi ograniczeniami, które utrudniają jego aplikację, a czasami nawet uniemożliwiają wykorzystanie takiej metody. Pierwszym utrudnieniem jest konieczność wykonywania pomiaru odległości mierzonego punktu konstrukcji od stałego punktu (najczęściej posadzki), co wiąże się $\mathrm{z}$ pewnymi ograniczeniami w swobodzie użytkowania obiektu (miejsca, do których są wykonywane pomiary nie mogą być zasłaniane) oraz wymaga zapewnienia odpowiedniej widoczności na drodze wiązki lasera. Utrudnieniem w wykorzystaniu pomiarów dalmierzami laserowymi jest też wrażliwość optyki na wilgoć i ujemne temperatury.

\section{Koncepcja metody pomiaru kątów}

Mając na uwadze niedoskonałości opisanych wyżej metod pomiaru przemieszczeń, podjęto próbę wykorzystania inklinometrów [7, 8], które mierząc zmiany kątów, pośrednio dostarczają informacji o przemieszczeniach rozumianych jako translacje. Mogłyby więc być one wykorzystane jako alternatywa i/lub uzupełnienie znanych metod pomiaru przemieszczeń, w szczególności przy pomocy dalmierzy laserowych. Ze względu na odmienną zasadę pomiaru przestają tu występować największe niedogodności stosowania dalmierzy laserowych, jakimi są: dostępność stałych miejsc, do których są wykonywane pomiary, odległość tych miejsc od monitorowanych punktów konstrukcji, a także czystość atmosfery. Również kwestia wilgoci i niskich temperatur nie jest już tak dużym problemem - po odpowiednim zabezpieczeniu elektroniki, inklinometry są całkowicie odporne na tego typu oddziaływania. Urządzenia te są też energooszczędne, co pozwala zakładać możliwość bezobsługowej pracy systemu nawet w okresie 10 lat, co z kolei umożliwia ich montaż w trudno dostępnych miejscach konstrukcji. 
Pojawia się natomiast inne zagadnienie - interpretacja wyników pomiarów kątów. W przypadku większości konstrukcji interpretacja ta jest znacznie bardziej złożona niż przy pomiarach ugięć i wymaga szerszej analizy konstrukcji.

W najprostszym przypadku belki jednoprzęsłowej, równomiernie obciążonej, ugięcie $w(x)$ i kąt obrotu $\varphi(x)$ można wyznaczyć następująco:

$$
\begin{aligned}
& w(x)=-\frac{q x}{24 E I}\left(l^{3}-2 l x^{2}+x^{3}\right) \\
& \varphi(x)=\frac{d w(x)}{d x}=-\frac{q}{24 E I}\left(l^{3}-6 l x^{2}+4 x^{3}\right)
\end{aligned}
$$

gdzie: q-obciążenie równomiernie rozłożone,

E - moduł sprężystości podłużnej,

I - moment bezwładności,

1 - rozpiętość belki,

$\mathrm{x}$ - odległość od podpory,

Krzywe obrazujące rozkład momentu zginającego oraz opisanych wyżej wielkości wraz z wartościami maksymalnymi, przedstawiono na rys. 3 .

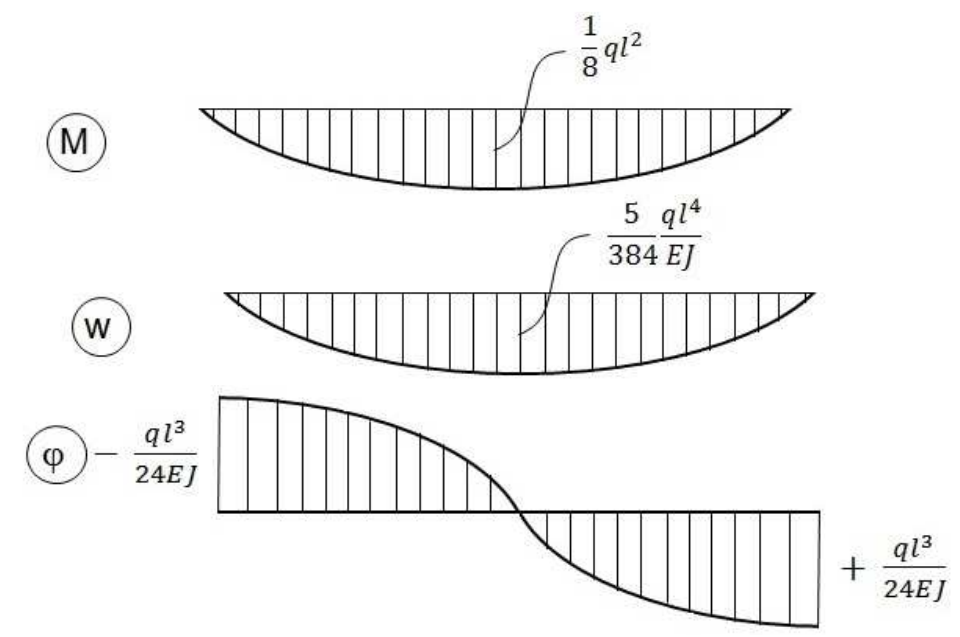

Rys. 3. Wykres momentu zginającego $\mathrm{M}(\mathrm{x})$, ugięcia $\mathrm{w}(\mathrm{x})$ i kąta obrotu $\varphi(\mathrm{x})$ belki swobodnie podpartej, równomiernie obciążonej

Fig. 3. Graph of the bending moment $\mathrm{M}(\mathrm{x})$, deflection $\mathrm{w}(\mathrm{x})$ and rotation angle $\varphi(\mathrm{x})$ of the simply supported, uniformly loaded beam

W powyższym przypadku występuje oczywiście jednoznaczna zależność pomiędzy poszczególnymi wielkościami. W celu przeanalizowania sytuacji obciążeń innych niż równomiernie rozłożone na całej długości elementu, przepro- 
wadzono symulacje numeryczne belki jednoprzęsłowej o przekroju IPE200 i rozpiętości $5 \mathrm{~m}$, poddanej obciążeniu zmieniającemu się od równomiernie rozłożonego na całej długości belki $\left(\mathrm{L}_{1}=\mathrm{L}\right)$ do zlokalizowanego na $1 / 10$ długości $\left(\mathrm{L}_{1}=\mathrm{L} / 10\right)$ - rys. 4 ., wariant 1 . Przeanalizowano też przypadek pełnego obciążenia na jednej połowie belki i $1 / 2$ obciążenia na drugiej części, a także zwiększone obciążenie lokalne o zmiennym położeniu (wariant 2 na rys. 4.). Założono pomiar ugięcia $(\mathrm{u}) \mathrm{w}$ środku rozpiętości belki i kątów $\left(\alpha_{1}, \alpha_{2}\right)$ w odległości 0,5 m od podpór. Koncepcja podwójnego, tzw. "różnicowego" pomiaru kątów ma na celu kontrolę obciążeń niesymetrycznych [9].

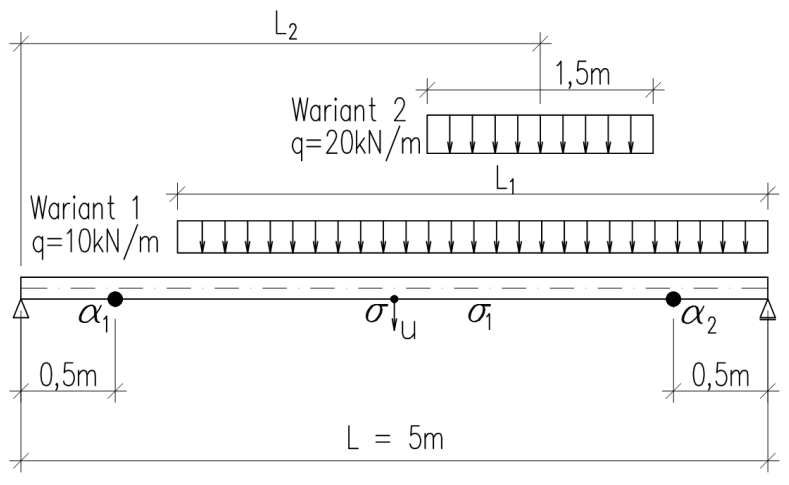

Rys. 4. Schematy: pomiarowy i obciążenia belki

Fig. 4. Schemes: measuring and loading of a beam

$\mathrm{Z}$ analizy wynika (porównanie kolumn i, k - tab. 1), że przy obciążeniach przyłożonych do co najmniej połowy belki, a także zgodnych z wierszem 11, proporcjonalność średniej wartości kąta obrotu $\left(\alpha_{\text {śr }}=\left(\alpha_{1}+\alpha_{2}\right) / 2\right)$ do naprężenia w środku rozpiętości $(\sigma)$ jest zachowana $\mathrm{z}$ dokładnością do około $7 \%$. W przypadku porównania średniego kąta obrotu do naprężenia maksymalnego $\left(\sigma_{1}\right)$ proporcjonalność jest zachowana $\mathrm{z}$ dokładnością do około 12\% (porównanie kolumn i, m). Przy obciążeniu znajdującym się na mniejszej części belki, rozbieżności rosną, wtedy jednak naprężenia maleją do poziomu poniżej typowych progów reakcji systemów monitoringu (około 30\% naprężeń od obciążeń zmiennych).

Znacznie korzystniej wygląda relacja pomiędzy zmianami kąta mierzonego po stronie bardziej obciążonej, a maksymalnym naprężeniem (porównanie kolumn $\mathrm{h}, \mathrm{m}$ ) - przy obciążeniach przyłożonych do co najmniej połowy belki, maksymalne rozbieżności oscylują, w tym przypadku, w okolicy 3\%. Przy obciążeniach mniejszych fragmentów belki rozbieżności sięgają kilkunastu procent - ma to jednak miejsce przy zmniejszających się naprężeniach.

W sytuacji obciążeń przyłożonych lokalnie (wiersze 12-16 - tab. 1.), rozbieżności proporcjonalności sięgają kilkunastu procent, zarówno w przypadku 
relacji średniej wartości kąta obrotu do naprężenia w środku rozpiętości jak i porównania kąta obrotu po stronie bardziej obciążonej do maksymalnego naprężenia.

Podobne relacje obserwowano w przypadku pomiaru ugięć (porównanie kolumn $\mathrm{d}$, $\mathrm{k}$ oraz kolumn $\mathrm{d}, \mathrm{m}$ ) - rozbieżności rosną wraz ze zmniejszaniem zakresu obciążenia.

Tabela 1. Zestawienie mierzonych wielkości dla belki z rys. 4 .

Table 1. Measured quantities for beam from fig. 4.

\begin{tabular}{|c|c|c|c|c|c|c|c|c|c|c|c|c|}
\hline Lp. & $\mathbf{L}_{\mathbf{1}} / \mathbf{L}$ & $\mathbf{u}[\mathrm{mm}]$ & $\mathbf{u} / \mathbf{u}_{\max }$ & $\alpha_{1}\left[^{0}\right]$ & $\boldsymbol{\alpha}_{2}\left[^{0}\right]$ & $\begin{array}{c}\alpha_{\text {ir }}= \\
\left(\alpha_{1}+\alpha_{2}\right) / 2\end{array}$ & $\alpha_{2} / \alpha_{\max }$ & $\alpha_{\mathrm{sr}} / \alpha_{\max }$ & $\begin{array}{c}\sigma \\
{[\mathrm{MPa}]}\end{array}$ & $\sigma / \sigma_{\max }$ & $\begin{array}{c}\sigma_{1} \\
{[\mathrm{MPa}]}\end{array}$ & $\left|\sigma_{1} / \sigma_{1 \max }\right|$ \\
\hline $\mathrm{a}$ & $\mathrm{b}$ & $\mathrm{c}$ & $\mathrm{d}$ & $\mathrm{e}$ & f & $\mathrm{g}$ & $\mathrm{h}$ & i & $\mathrm{j}$ & $\mathrm{k}$ & 1 & $\mathrm{~m}$ \\
\hline 1 & 1,00 & 20,5 & 1 & 0,708 & 0,708 & 0,708 & 1 & 1 & 241,62 & 1 & 241,62 & 1 \\
\hline 2 & 0,90 & 20,0 & 0,975 & 0,687 & 0,694 & 0,6905 & 0,980 & 0,975 & 236,79 & 0,980 & 236,81 & 0,980 \\
\hline 3 & 0,80 & 18,6 & \begin{tabular}{|l|l|}
0,907 \\
\end{tabular} & 0,624 & 0,651 & 0,6375 & 0,919 & \begin{tabular}{|l|l|}
0,900 \\
\end{tabular} & 222,29 & \begin{tabular}{|l|}
0,920 \\
\end{tabular} & 222,63 & 0,921 \\
\hline 4 & 0,70 & 16,3 & 0 & 0,533 & 0,583 & 0,558 & 0 & \begin{tabular}{|l|}
0,788 \\
\end{tabular} & \begin{tabular}{|l|}
198,13 \\
\end{tabular} & $0,0,820$ & 200,07 & \begin{tabular}{|l|l|}
0,828 \\
\end{tabular} \\
\hline 5 & 0,60 & 13,4 & 0,654 & 0,427 & 0,495 & 0,461 & 0,699 & 0,651 & 164,30 & 0,680 & 170,49 & 0,706 \\
\hline 6 & 0,50 & 10,2 & 0,499 & 0,317 & 0,391 & 0,354 & 0,552 & 0,500 & 120,81 & 0,500 & 135,91 & 0,562 \\
\hline 7 & 0,40 & 7,0 & 0,341 & 0,214 & 0,282 & 0,248 & 0,398 & 0,350 & 77,32 & 0,320 & 98,97 & 0,410 \\
\hline 8 & 0,30 & 4,2 & 0,205 & 0,125 & 0,175 & 0,150 & 0,247 & 0,212 & 43,49 & 0,180 & 62,84 & 0,260 \\
\hline 9 & 0,20 & 1,9 & 0,093 & 0,057 & 0,084 & 0,0705 & 0,119 & 0,100 & 19,33 & 0 & 31,31 & 0,130 \\
\hline 10 & 0,10 & 0,5 & 0,024 & 0,014 & 0,022 & 0,018 & 0,031 & 0,025 & 4,83 & 0,020 & 8,70 & 0,036 \\
\hline \multirow[t]{2}{*}{$11^{*}$} & $\begin{array}{l}0,25 \\
+0,5\end{array}$ & 15,3 & 0,746 & 0,513 & 0,550 & 0,5315 & 0,777 & 0,751 & 181,22 & 0,75 & 184,99 & 0,766 \\
\hline & $\mathbf{L}_{2} / \mathbf{L}$ & & & & & & & & & & & \\
\hline 12 & 0,50 & 18,8 & 0,917 & 0,628 & 0,628 & 0,628 & 0,887 & 0,887 & 246,46 & 1,020 & 246,46 & 1,020 \\
\hline 13 & 0,60 & 17,8 & 0,868 & 0,567 & 0,635 & 0,601 & $\mathbf{0 , 8 9 7}$ & 0,849 & 227,13 & 0,940 & 236,58 & 0,979 \\
\hline 14 & 0,70 & 15,0 & 0,732 & 0,463 & 0,577 & 0,520 & 0,815 & 0,734 & \begin{tabular}{|l|}
173,97 \\
\end{tabular} & 0,720 & 207,02 & 0,857 \\
\hline 15 & 0,80 & 10,8 & $\mathbf{0 , 5 2 7}$ & 0,327 & 0,444 & 0,3855 & 0,627 & 0,544 & 115,98 & 0,480 & 157,73 & 0,653 \\
\hline 16 & 0,85 & 8,3 & 0,405 & 0,250 & 0,350 & 0,300 & 0,494 & 0,424 & 86,99 & 0,360 & 125,68 & 0,520 \\
\hline
\end{tabular}

${ }^{*}$ Wiersz 11 - obciązenie równomiernie rozłożone na prawej połowie oraz $50 \%$ obciązenia równomiernie roztożonego na lewej potowie.

Analogiczne symulacje przeprowadzono dla innych rodzajów ustrojów konstrukcyjnych - belek ciągłych, kratownic i układów ramowych. Wynika z nich, że wykorzystanie pomiaru kątów obrotu w systemie monitoringu jest możliwe, a uzyskiwane wyniki mogą stanowić wiarygodne źródło informacji o zachowaniu się konstrukcji. W przypadku obciążeń równomiernie rozłożonych, zgodnych z normowymi schematami obciążenia śniegiem i zbliżonych do powyższych, zmiany kątów obrotu w charakterystycznych punktach ustroju konstrukcyjnego są praktycznie proporcjonalne do zmian naprężeń $\mathrm{w}$ miejscu, w którym są one maksymalne. Przy mniej typowych rozkładach obciążeń rozbieżności w proporcjonalności zmian kątów obrotu i maksymalnych naprężeń rosną, pozostając jednak na akceptowalnym poziomie, na ogół kilku procent. 
Dopiero przy obciążeniach bardzo nietypowych, np. małych fragmentów ustroju, rozbieżności znacząco rosną do kilkunastu albo nawet 20-30\%, wtedy jednak naprężenia od obciążeń zmiennych (a więc tych monitorowanych) są na tak niskich poziomach, że wykraczają poza dolny próg reakcji systemu monitoringu.

\section{Praktyczne wykorzystanie inklinometrów w systemie monitoringu}

Bazująca na inklinometrach, metoda monitoringu przemieszczeń konstrukcji, opracowana w firmie WiSeNe została wykorzystana m.in. w systemie zainstalowanym w obiekcie o stalowej konstrukcji nośnej, z przegubowo opartymi na słupach dźwigarami kratowymi o rozpiętości $36 \mathrm{~m}$. Rozstaw dźwigarów wynosi $6 \mathrm{~m}$, a długość hali $96 \mathrm{~m}$. Fragment rzutu hali z rozmieszczeniem czujników pokazano na rys. 5 . W obiekcie zainstalowano łącznie 9 czujników inklinometrycznych umieszczonych na dolnych pasach dźwigarów - rys. 6 . W dwóch przypadkach zlokalizowano je na obu końcach kratownic, a w pozostałych, na jednym końcu. Przyjmując takie rozwiązanie założono równomierny i symetryczny rozkład obciążeń śniegiem, a instalacja czujników na obu końcach dwóch dźwigarów miała na celu kontrolę przebiegu tego schematu obciążenia i dostarczenie informacji o ewentualnych odstępstwach od tego założenia.

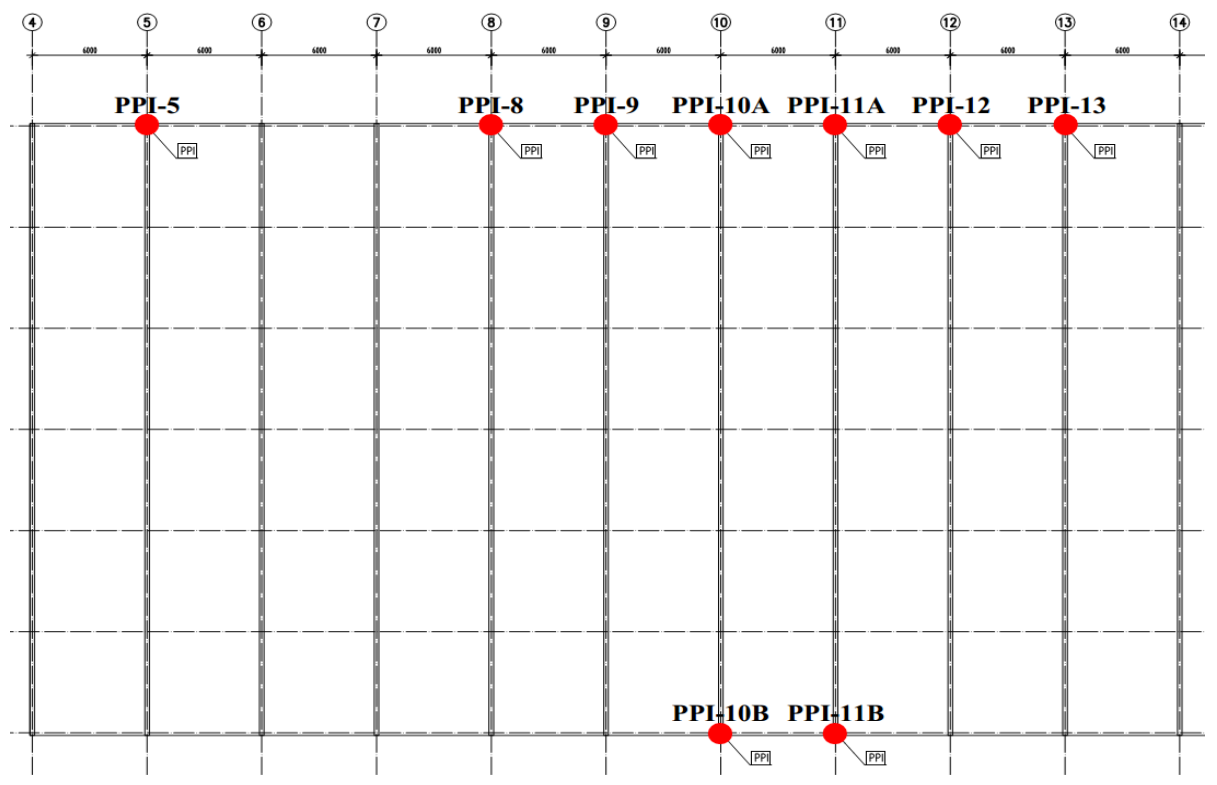

Rys. 5. Schemat instalacji systemu WiSeNe

Fig. 5. Installation scheme of the WiSeNe system 


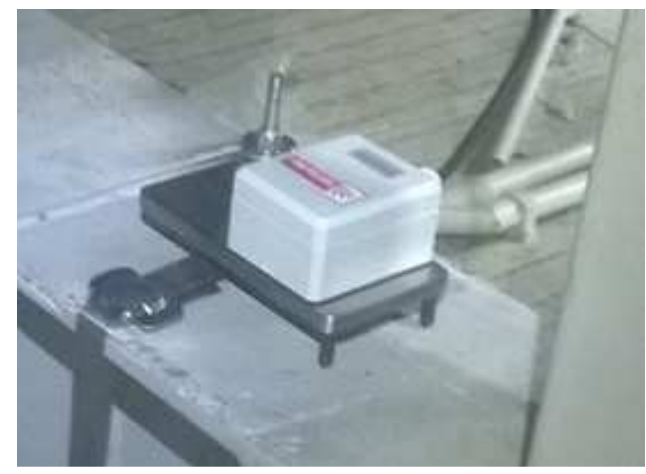

Rys. 6. Montaż czujnika inklinometrycznego na pasie dolnym dźwigara

Fig. 6. Assembly of the inclinometer sensor on the bottom chord of the girder

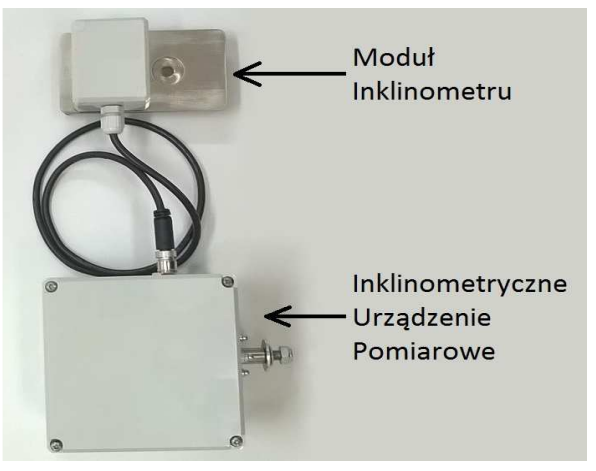

Rys. 7. Urządzenie pomiarowe $\mathrm{z}$ inklinometrem

Fig. 7. Measuring device with inclinometer

Bazujące na inklinometrze urządzenie pomiarowe składa się z Modułu Inklinometru zawierającego czujnik pomiarowy oraz układu sterującego zapewniającego współpracę i łączność z pozostałymi elementami systemu - rys. 7. W Module Inklinometru zastosowano czujnik inklinometryczny wykonany w technologii MEMS (ang. Micro-Electro-Mechanical Systems) mierzący kąt pomiędzy osią czułości Modułu Inklinometru i płaszczyzną poziomą (prostopadłą do wektora pola grawitacji). Odniesieniem jest tu więc stabilne i dostępne zawsze i wszędzie pole grawitacji ziemskiej, a czujnik może pracować w temperaturach od $-20^{\circ} \mathrm{C}$ do $+60^{\circ} \mathrm{C}$. Nie ma zatem ograniczeń środowiskowych, jakie występowały przy pomiarach $\mathrm{z}$ wykorzystaniem dalmierzy laserowych. Zakres pomiarowy czujnika wynosi $4,5^{\circ}$, a całkowity błąd pomiaru mieści się $\mathrm{w}$ zakresie $\pm 0,01^{\circ}$.

Poza urządzeniami pomiarowymi, w skład systemu wchodzą także retransmitery (wykorzystywane do komunikacji pomiędzy elementami systemu), urządzenie dostępowe oraz zarządzająca całością jednostka centralna. Oprócz urządzeń inklinometrycznych, w systemie mogą być równolegle wykorzystywane czujniki przemieszczeń liniowych bazujące na dalmierzach laserowych. Komunikacja pomiędzy zainstalowanymi na konstrukcji urządzeniami realizowana jest bezprzewodowo. Wszystkie urządzenia pomiarowe i retransmisyjne zasilane są $\mathrm{z}$ baterii, a jedynym elementem systemu wymagającym zewnętrznego źródła zasilania jest jednostka centralna, która w przypadku awarii sieci przełącza się automatycznie na zasilanie z wbudowanego UPS. Poszczególne urządzenia systemu komunikują się pomiędzy sobą z wykorzystaniem radiowej transmisji danych, a komunikacja z systemem odbywa się przez stronę WWW. System cyklicznie, w odpowiednio dobranych odstępach czasowych, zbiera i analizuje, uzyskiwane $\mathrm{z}$ urządzeń pomiarowych, informacje o zmianach kątów obrotu re- 
prezentatywnych elementów konstrukcji wywołanych obciążeniem, np. śniegiem lub wodą opadową. W przypadku współwystępowania czujników przemieszczeń liniowych, zbierane i przetwarzane są także informacje o zmianach tych przemieszczeń.

Zarządzająca pracą systemu jednostka centralna, na podstawie danych pomiarowych, generuje komunikaty o stopniu zagrożenia przeciążeniem konstrukcji obiektu i stanie systemu. Jednostka ta jest także odpowiedzialna za komunikację pomiędzy systemem a użytkownikami.

System wykrywa szereg zdarzeń dotyczących monitorowanej konstrukcji, a także związanych z działaniem samego systemu i reaguje na nie odpowiednimi komunikatami: informacjami (nie ma wymogu reakcji), ostrzeżeniami (wymóg inspekcji i ewentualnie interwencji) lub alarmami (wymóg bezwzględnej interwencji). Najważniejszym zdarzeniem wykrywanym przez system jest przekraczanie kolejnych poziomów (tzw. wartości progowych) kąta obrotu elementów konstrukcji w miejscach instalacji czujników. Na podstawie porównania mierzonych wartości zmiany kąta $\mathrm{z}$ wartościami progowymi, określany jest stopień zagrożenia przeciążeniem konstrukcji/wykorzystania nośności elementów konstrukcji i rodzaj generowanego komunikatu. Dla każdego punktu pomiarowego zdefiniowana jest indywidualna wartość dopuszczalnej zmiany kąta obrotu od obciążeń występujących po zainstalowaniu systemu oraz wartości progowe L1 L4 - odpowiednio 30\%, 50\%, 70 oraz 100\% dopuszczalnej zmiany kąta obrotu. Dopuszczalna zmiana wartości kąta obrotu waha się w przypadku poszczególnych punktów w przedziale od 0,320 do $0,380^{\circ}$.

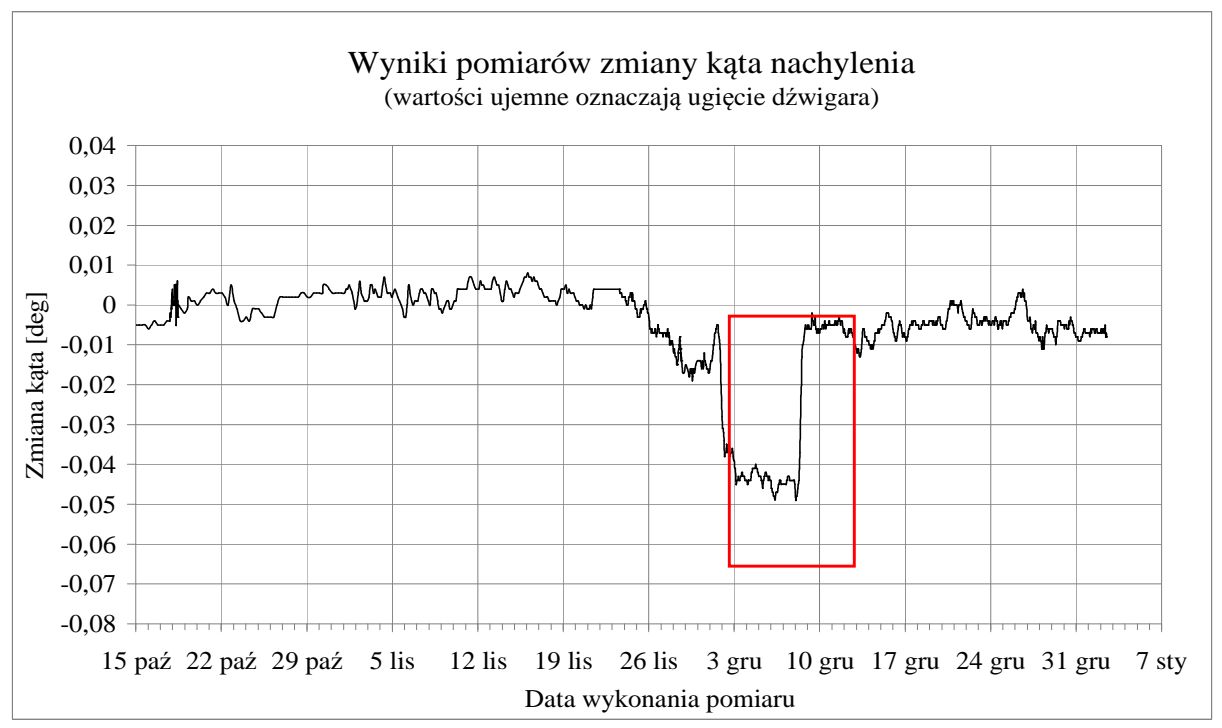

Rys. 8. Przykładowe wyniki pomiarów

Fig. 8. Sample measurement results 
Przekraczanie kolejnych wartości progowych determinuje typ komunikatów generowanych przez system i wysyłanych do użytkowników w formie SMS i/lub e-mail (informacje, ostrzeżenia i alarmy), częstotliwość pomiarów (zwiększana wraz z przekraczaniem kolejnych progów) oraz pożądane działania użytkowników (inspekcja lub interwencja).

Przykładowe wyniki pomiarów jednego z czujników przedstawiono na rys. 8. Znacząca zmiana kąta została zarejestrowana 1 grudnia 2016 roku i była ona związana z opadami śniegu. Następnie, 8 grudnia nastąpiło stopienie śniegu, co znajduje odzwierciedlenie w zmianie/zmniejszeniu kąta z 0,05 do 0,005 stopnia. Maksymalna zmiana wyniosła więc 0,05 stopnia, podczas gdy pierwszy próg (L1) wynosił w tym przypadku 0,1 stopnia - oznacza to, że nie został on osiągnięty i nie nastąpiła żadna reakcja systemu.

\section{Podsumowanie}

Bazująca na inklinometrach metoda monitoringu przemieszczeń konstrukcji budowlanych jest rozwiązaniem, które może zastąpić i/lub uzupełnić wykorzystywane aktualnie dalmierze laserowe. Inklinometry charakteryzują się korzystnymi właściwościami metrologicznymi, a metoda jest pozbawiona największych niedogodności związanych ze stosowaniem dalmierzy laserowych. Inklinometry, po odpowiednim zabezpieczeniu elektroniki, nie są wrażliwe na typowe warunki klimatyczne i nie wymagają zewnętrznej bazy odniesienia - jest nią tu pole grawitacji. Są ponadto bardziej energooszczędne, co w przypadku systemów zasilanych bateryjnie ma zasadnicze znaczenie dla komfortu obsługi. Stosunkowo istotnym utrudnieniem $\mathrm{w}$ stosowaniu inklinometrów w monitoringu konstrukcji jest natomiast większa niż w przypadku dalmierzy laserowych, trudność w wyznaczeniu odpowiednich miejsc pomiaru i wartości dopuszczalnych przemieszczenia kątowego. Wymaga to bardziej zaawansowanej analizy konstrukcji, niż w przypadku systemów wykorzystujących dalmierze.

$W$ przygotowaniu publikacji wykorzystano wyniki badań zrealizowanych $w$ ramach projektu Nr UDA-POIG.01.04.00-14-109/13-03 oraz projektu MONIT - „Monitorowanie Stanu Technicznego Konstrukcji i Ocena jej Żywotności”, wspótfinansowanych przez Unię Europejska ze środków Europejskiego Funduszu Rozwoju Regionalnego w ramach Programu Operacyjnego Innowacyjna Gospodarka.

\section{Literatura}

[1] Giżejowski M., Antoszkiewicz E., Wierzbicki S., Pióro Z., Wireless Sensor Network Systems for Structural Health Monitoring of Building Structures. Proceedings of the 5th International Conference on Structural Health Monitoring of Intelligence Infrastructure, Cancun, Mexico (SHMII-5), 2011, p. 34 [full text on CD].

[2] Giżejowski M., Wilde K., Uziak J., Wierzbicki S., On a Necessity of Monitoring Systems for Sustainable Development of Mechanical and Civil Engineering Infrastructure. Botswana Journal of Technology, 2011, vol. 19, number 2, p. 9-20. 
[3] Wierzbicki S., Giżejowski M., Stachura Z., Structural Failures and Monitoring of Structural Health with Use of WiSeNe ${ }^{\text {MONIT }}$ System. Research and Applications in Structural Engineering, Mechanics and Computation, CRC PRESS/BALKEMA: Proceedings and Monographs in Engineering, Water and Earth Sciences, 2013, p. 2365-2370, full text e-book.

[4] Rozporządzenie Ministra Infrastruktury z dnia 12 marca 2009 r. zmieniające rozporządzenie w sprawie warunków technicznych, jakim powinny odpowiadać budynki i ich usytuowanie (Dz.U. z 2009 r. Nr 56 poz. 461, §204, ust. 7).

[5] Wilde K., Zautomatyzowane systemy monitoringu technicznego dachów stalowych. 56 Konferencja Naukowa KILiW PAN oraz KN PZITB, Krynica 2010, Wyd. Konf. Tom 2, str. 729-736.

[6] Wierzbicki S.: Monitoring konstrukcji stalowych. Cz.2, w: Builder, PWB MEDIA, vol. 20, nr 8, 2016, ss. 60-63.

[7] Osiniak M., Pióro Z., Jakubowski A., Wierzbicki S.: Koncepcja wykorzystania inklinometrów z czujnikami MEMS do monitorowania obciążenia konstrukcji dachów, Elektronika: konstrukcje, technologie, zastosowania, 7/2016, ss. 41-44.

[8] Osiniak M., Pióro Z., Jakubowski A., Wierzbicki S.: Możliwość realizacji inklinometru z czujnikiem MEMS dla systemów monitorowania obciążenia konstrukcji dachów, Elektronika: konstrukcje, technologie, zastosowania, 1/2017, ss. 37-42.

[9] Pióro Z., Antoszkiewicz E., Osiniak M., Wierzbicki S., zgłoszenie patentowe P.419218 pt. „Sposób monitorowania obciążenia zmiennego konstrukcji dachu” $\mathrm{z}$ dnia 21.10.2016 roku.

\section{APPLICATION OF INCLINOMETERS IN STRUCTURE MONITORING}

\section{S u m m a r y}

The paper discusses the problem of measuring local changes of rotation angles of structural elements as a method of monitoring the behavior of structure. The purpose of the research and analysis is to develop a measurement method that could be used in structure monitoring systems as an alternative to conventional laser distance measurement. Inclinometers with MEMS sensors having good metrological properties at acceptable costs, were proposed. The advantages and limitations of this method have been analyzed in relation to the alternative measurement of displacement with laser rangefinders. The possibility of using inclinometers to monitor of typical structures is discussed, as well as an example of a technical monitoring system using such a measurement method.

Keywords: structure monitoring, displacement measurements, rotation angles measurements, MEMS inclinometer, wireless system 